\title{
Hypocupraemia in Dairy Cows
}

\author{
BY RUTH ALLCROFT \\ Veterinary Laboratory, Ministry of Agriculture, Weybridge, Surrey \\ AND W. H. PARKER \\ Veterinary Laboratory, Ministry of Agriculture, Tettenhall, Staffs.
}

(Received 28 April 1949)

Although Neal, Becker \& Shealy (193I) appear to have been the first to suggest that deficiency of copper occurs naturally in livestock, it was Sjollema (1933) who first described a disease of plants and animals in parts of Holland which could be controlled by administration of copper. In cattle, goats and sheep the disease, a form of 'Lecksucht', was characterized by anorexia, emaciation, anaemia and diarrhoea.

The most valuable subsequent work indicating the importance of copper metabolism in ruminants was carried out in Western Australia by Bennetts \& Chapman (1937) and by Bennetts \& Beck (1942) who showed that enzootic ataxia of lambs, a demyelinating disease developing in the foetus during late gestation, was preventable by administration of small amounts of copper during pregnancy. The occurrence of the disease was shown to be associated with a low copper content of the pastures and a low copper status of both ewes and ataxic lambs. The same condition occurs in sheep in other parts of Australia and also in New Zealand in limited areas. The disease, swayback, in lambs is widespread in Great Britain and has been shown by Innes \& Shearer (1940) to correspond pathologically to the enzootic ataxia of Australasia. It differs from the Australian condition, however, in that it is not due to a simple copper deficiency of the herbage. The copper content of affected Australian pastures is below 5 p.p.m., whereas in Great Britain the apparently identical disease is recorded on pastures of normal copper content ranging from 7 to 23 p.p.m. in the dry matter.

In certain areas in Western Australia where ataxia occurs in lambs, an enzootic disease of dairy cattle, characterized by loss of condition and sudden death, has been reported by Bennetts \& Hall (1939). The clinical symptoms of 'sudden death' or 'falling disease' are evident in adult cattle, especially during the flush growth of pasture in spring when, in spite of this, there is loss of condition, development of rough staring coats and often anaemiz and depraved appetite. The syndrome somewhat resembles that described by Sjollema (1938) and by Brouwer, Frens, Reitsma \& Kalisvaart (1938) in Holland, but diarrhoea, although sometimes present, is not a characteristic of the condition in Australia. These conditions, both in Holland and Australia, can be cured and prevented by administration of copper.

A copper deficiency disease called 'peat scours' has been reported in cattle on peat land in New Zealand by Cunningham (1944). The most characteristic symptoms of the acute form affecting dairy cattle are loss of condition, and persistent severe diarrhoea which occurs whenever there is a flush growth of pasture; symptoms in beef cattle 
differ in that scouring is not a prominent symptom. In both types of cattle difficulty is experienced in getting cows in calf. The pastures on which 'peat scours' occurs were found to be deficient, or moderately deficient, in copper, values ranging from $1 \cdot 7$ to II.3 P.p.m. in the dry matter being reported (Cunningham 1946). Blood- and livercopper values of animals on peat lands were all low compared with values of normal animals grazing healthy areas.

The first suspicion of copper deficiency of cattle in Great Britain was reported by Jamieson \& Russell (1946) on land newly reclaimed from heather in Aberdeenshire. Scouring, emaciation and anaemia were features of the condition, but no blood- or liver-copper values were obtained to confirm the condition. A single spectographic pasture analysis showed a copper content of 2.5 p.p.m. In the same year Allcroft (1946) demonstrated low blood-copper values in cattle suffering from a severe chronic scouring disorder in a small dairy herd on peat land on the border of Shropshire and Cheshire. The occurrence on peat land and the clinical condition of the animals suggested analogy with 'peat scours' in New Zealand, although the pastures showed normal copper values of more than jo p.p.m., and haemoglobin values of the affected animals were also normal.

The condition now described is similar to that briefly reported by Allcroft (1946), and was found to occur on a larger neighbouring dairy farm in the same area. Since the owner was willing to co-operate experimentally, it was decided to carry out controlled observations on this larger farm rather than on the smaller farm where the disorder was first observed.

\section{EXPERIMENTAL}

\section{Experimental farm}

The farm is a 70-acre holding situated entirely on lacustrine peat $5 \mathrm{ft}$. or more in depth. The land is flat and nearly all just below sea-level. Soil analyses showed features typical of many peat soils, i.e. $\mathrm{pH}$ ranging from $4 \cdot 7$ to 6.4 , satisfactory available potash but available phosphorus on the low side. Pasture samples were taken from six fields at approximately quarterly intervals throughout the year and copper and molybdenum content was determined.

\section{Clinical condition of cattle}

Severe chronic diarrhoea was a characteristic feature, especially during the flush growth of grass in spring and autumn, but it persisted even during the summer when the grass was more mature. It was less severe when the cattle were housed for the winter. Because of this almost permanent state of scour, the cows were naturally in poor condition with rough staring coats and gave low milk yields, but it was in the young stock between weaning and calving that unthriftiness was most marked. These animals did not thrive and were severely stunted, so much so that 2-year-old pregnant heifers could be mistaken for calves 8-10 months old. The fertility record of the herd was not good and milk production was very low indeed. Examination of faeces for worm eggs gave negative results or showed only insignificant infestation. Cases of lung-worm infestation occurred from time to time in young calves but these did not account for the general unthriftiness. 
Because of the similarity to 'peat scours' in New Zealand (Cunningham, r944), and because low blood-copper values had been found in animals on a neighbouring farm suffering from a similar clinical condition (Allcroft, r946), the present experiments were carried out to obtain more information on the disorder and to observe the effect of administration of copper alone and with other trace elements.

\section{Experimental herd}

Composition. The herd consisted of about forty-two animals of all ages with a fluctuating milking nucleus of about twenty-six cows. The milking cows were divided into three roughly equal groups, A, B and C, and each group occupied a separate byre for milking or when stalled during winter months. Calves were kept inside until 8-10 months old, but were allowed out for grazing on the home field when weather was suitable. Heifers and milking cows were at pasture for the greater part of the year but were housed for 3-4 months during the winter. The general level of nutrition on the farm was not good, owing to the fact that very poor crop yields were obtained on the peaty land, and as milk production was low, allowance of rationed feeding stuffs was also very small.

Treatment. Daily administration of copper alone or with other trace elements to groups $A$ and B was commenced on 22 August 1947 in the form of cake with added copper or of mineralized cubes. Group A was given I lb./head/day of 'anti-teart' cake which supplied daily approximately $2 \mathrm{~g}$. copper sulphate or $500 \mathrm{mg}$. copper. Group B received $0.5 \mathrm{lb}$./head/day of a semi-proprietary brand of mineralized cubes which supplied daily approximately $160 \mathrm{mg}$. copper together with $20 \mathrm{mg}$. cobalt and $60 \mathrm{mg}$. iodine as well as $21.6 \mathrm{~g}$. calcium, $10 \mathrm{~g}$. phosphorus, $12 \mathrm{~g}$. sodium, $18.6 \mathrm{~g}$. chlorine, $0.5 \mathrm{~g}$. iron, $3.2 \mathrm{~g}$. sulphur, ${ }^{5} 5^{\circ} \mathrm{mg}$. manganese and $20 \mathrm{mg}$. nickel. Group $\mathrm{C}$ was given no mineral supplement and served as a control. Since 'anti-teart' cake is a high protein cake in which copper sulphate is incorporated, groups $B$ and $C$ were fed an additional $\mathrm{I} l \mathrm{lb}$. of concentrates to balance up the additional I lb. supplied to group $\mathrm{A}$ by the 'anti-teart' cake. As the groups were housed in separate byres, and the cake with copper or the cubes were given individually with other concentrates during the afternoon milking period, there was very little chance of the control animals getting copper supplements by mistake.

The calves were left untreated.

Blood constituents. Blood samples were taken from the cows for copper and haemoglobin determinations in June, and again early in August, 1947, before any treatment was started, and subsequently at monthly intervals throughout a period of 14 months. Copper and haemoglobin values were followed throughout the same period in a group of six calves varying in age from 1 to 4 months at the beginning of the observations.

From March until October 1948 blood-molybdenum values were determined on three cows from each group for the sake of comparison with 'teart' areas in Somerset. Some haematological studies were also made on three animals in each group from June to September 1948 . 


\section{Transferred animals}

At the beginning of the experiment in August 1947 four animals were sent from the experimental farm in Cheshire to the laboratory at Weybridge. One, cow $R$, an aged animal which had been on the farm for about 8 years and was in very poor condition, was killed on arrival for post-mortem examination. The other three, consisting of two 2-year-old heifers (nos. I 152 and I 153 ) and one 6-month-old calf (no. I 154) were also in poor condition and very stunted in size. They were given no special treatment, but merely kept on the laboratory fields to see if transference to healthy pastures would improve their condition and increase the blood-copper values. The two heifers were left out at grass until they calved in August 1948 after which they were kept in stalls and fed hay and concentrates. In October 1948 the calf was also brought in and kept under stall conditions. Blood samples were taken at fortnightly intervals.

Early in March 1948 heifer no. II 53 was injected intravenously with $200 \mathrm{mg}$. copper as copper sulphate in normal saline to see if this amount of copper would elevate the blood to normal levels and maintain it at those levels.

\section{Neighbouring farms}

Blood samples were taken from cattle on three neighbouring farms, L.E., S. and L.W., which had some peat-land grazing, to compare blood-copper values with those of the animals on the experimental farm. On farm L.E. the cattle grazed on peat land almost entirely, but hay and crops were grown on higher land consisting of good loam; on farm S. the cattle were never confined to peat-land grazing for any length of time since only a small portion of the farm was peat. Farm L.W. was very small and consisted of only three large fields, two of which were entirely peat and were the ones most used for grazing. Chronic diarrhoea was very severe in the animals on this farm and their condition and production so poor that it was almost impossible for the farmer to continue. Since there were eight milking cows it was possible to observe on this farm the effect of daily drenching with 2 g. A.R. copper sulphate over a period of 6 weeks. After that the cows were put on to $\mathrm{I} \mathrm{lb}$. of 'anti-teart' cake daily, which supplied about 2 g. copper sulphate.

\section{Analytical methods}

Copper was estimated by the method of Eden \& Green (1940), molybdenum by the method described by Perrin (1946) and haemoglobin by the acid-haematin method of Newcomer (1923).

\section{Pastures}

RESULTS

Experimental farm

Samples of herbage taken from six fields at intervals throughout the year gave normal copper values ranging from 8.7 to $22 \cdot 7$ p.p.m. on a dry-matter basis, with a mean of $14 \cdot 2$ p.p.m. Molybdenum values ranged from $2 \cdot 3$ to $7 \cdot 4$ p.p.m. in the dry matter with a mean of 4.4 p.p.m. These are slightly higher than the usual normal of $I-2$ p.p.m., 
but do not approach the teart-pasture values of $15-80$ p.p.m. found in Somerset by Ferguson, Lewis \& Watson (1943). The copper and molybdenum contents $\mathrm{Cf}$ the laboratory pastures averaged $11 \cdot 4$ and $1 \cdot 3$ P.p.m. in the dry matter respectively.

\section{Cows}

Blood-copper values. Average monthly values for groups A, B and C over a period of 16 months are shown in Fig. I. It is obvious that administration of copper to groups $A$ and $B$ resulted in an immediate and marked elevation of blood-copper values and that the elevation in group $A$, which received about three times as much copper as group B, was greater, as would be expected.

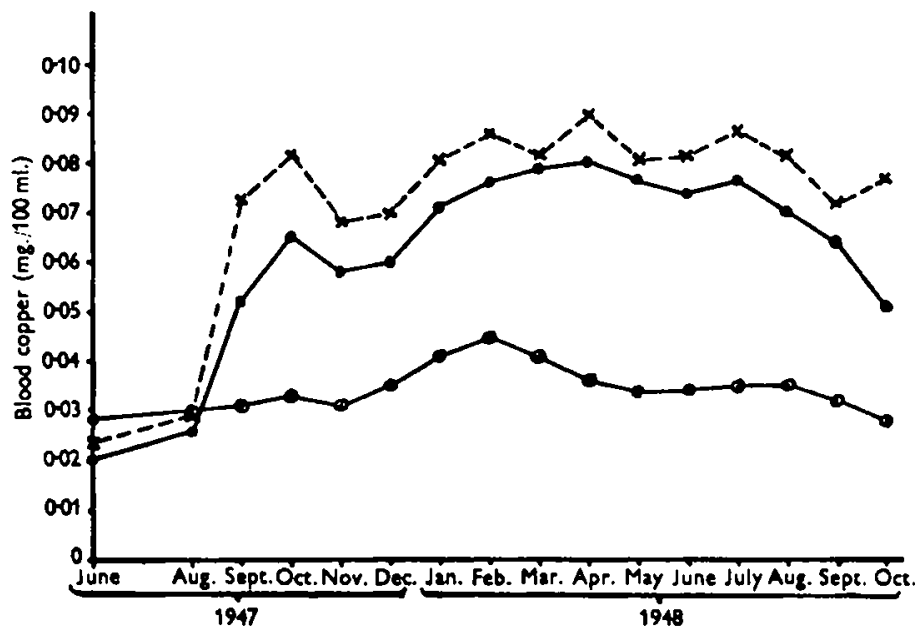

Fig. 1. Average monthly copper values of three groups of cows. $\times \cdots---\times$, group A (eight cows) which received daily approx. $0.5 \mathrm{~g}$. copper per head in a cattle cake with added copper; -0 , group B (seven cows) which received daily approx. $0.16 \mathrm{~g}$. copper per head with other minerals in mineralized cubes; $\odot-\bigcirc$, group $C$ (five cows), control, no supplements.

Improvement in clinical condition in the two treated groups was evident a month or two after commencement of feeding of the cake with copper or of the mineralized cubes. The consistency of the dung became firmer, and the previous persistent scouring was controlled. Improvement was most marked and rapid in group A, which received the larger amount of copper, and throughout the experiment this group remained in slightly better condition that group B. This may have been due in part to the fact that the mineralized cubes given to group B were not very palatable and the cows sometimes refused them even though they were given individually and mixed with concentrates and chopped roots. There was never any difficulty with the consumption of 'anti-teart' cake; the cows usually finished it up first before eating other concentrates.

The small decline in blood-copper values from October to December 1947 in groups A and B cannot be accounted for nor correlated with any change in clinical condition.

Another slight decline uncorrelated with any obvious change in clinical condition again occurred in group A from July to September 1948, but levels were increasing 
again in October, and by November had reached an average of $0.10 \mathrm{mg} . / 100 \mathrm{ml}$., but this last figure is not shown in Fig. $x$. The decrease in group B from July to September 1948 was probably due to the fact that one or two cows consistently refused to eat their full ration of mineralized cubes over this period, but the sharper decrease from September to October can be correlated with cessation of feeding the cubes at the beginning of October.

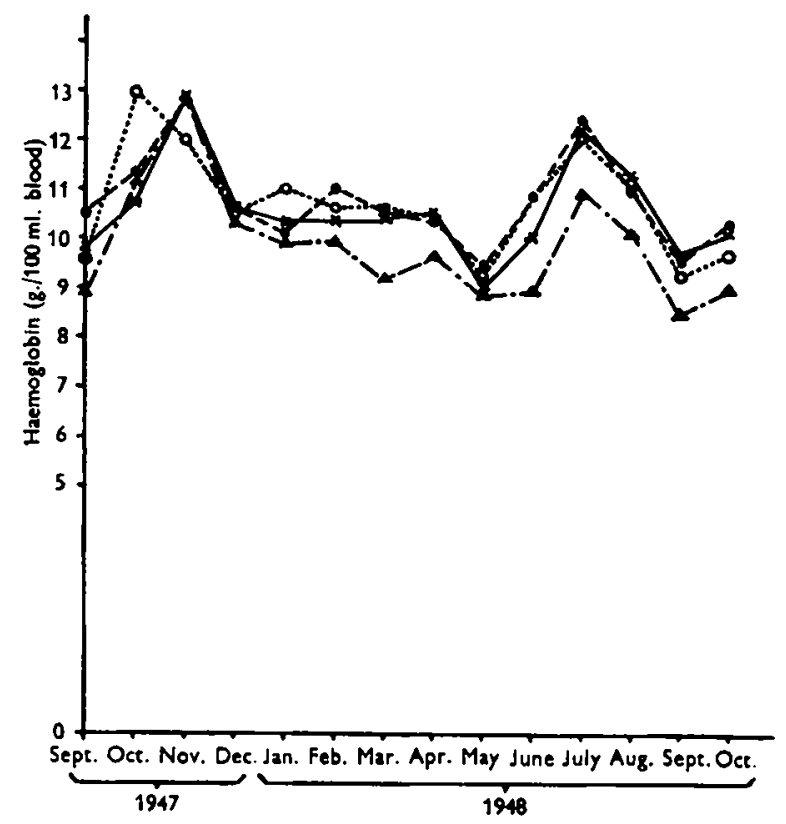

Fig. 2. Mean monthly haemoglobin values for three groups of cows and calves. $\times-\times$, group $A$ (eight cows) which received daily approx. $0.5 \mathrm{~g}$. copper per head in a cattle cake with added copper; -...- group B (seven cows) which received daily approx. $0.16 \mathrm{~g}$. copper per head with other minerals in mineralized cubes; $\mathbf{A}-.-\Delta$, group $\mathrm{C}$ (five cows), controls, no supplements; $0-. .-0$, calves (six animals), no supplements.

The consistently low values obtained for the control group $\mathrm{C}$ are as expected and could be correlated with the continued unthrifty condition and diarrhoea in this group. The slight increase from November to April coincided with winter management when the animals were kept inside until April because of the wet conditions prevailing in the early part of that year. Since less home-grown food is fed during the winter it is probable that more 'available' copper is present in the diet during this period.

Blood-molybdenum values. These remained below $0.08 \mathrm{mg} / \mathrm{l}$. and were similar in this respect to values found in normal animals grazing the laboratory pastures with a molybdenum content of I-2 p.p.m.

Haemoglobin values. Mean values are given in Fig. 2. It is unfortunate that the estimations were not done on the blood samples taken in August 1947 just before treatment began, but values on blood from three animals in each group taken in June 1947 ranged from 9.1 to $11.8 \mathrm{~g} . / 100 \mathrm{ml}$. with a mean of 10.3 which is very similar to the September 1947 values shown in Fig. 2. 
It can be seen that the haemoglobin values for all groups were very variable, but from December 1947 the control group maintained a slightly lower level than the two groups receiving copper supplements. Limited haematological studies indicated that there was no anaemia, red blood-cell counts for all groups ranged from 5.7 to $8.2 \times 10^{6} / \mathrm{cu} . \mathrm{mm}$.

The two peaks in haemoglobin values occurring in November 1947 and July 1948 cannot be explained on any obvious grounds, but it is probable that they were associated with slightly better nutritional levels at these times.

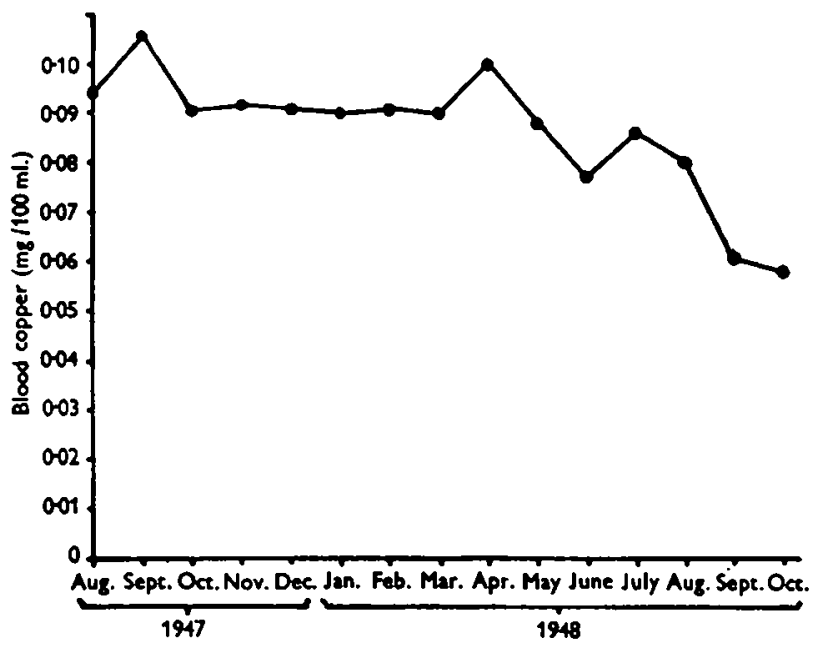

Fig. 3. Average monthly blood-copper values of a group of six calves I-4 months of age at the beginning of the experiment. No supplements given.

Pathological examination. Unfortunately only one animal, cow $\mathrm{R}$, showing marked clinical symptoms of the disorder, was available for post-mortem examination from this farm. Histological examination of tissues showed slight degenerative changes in the muscle fibres of the heart, but the nuclei were untouched. The spleen contained few red blood cells but macrophages packed with haemosiderin were conspicuous. In the liver there were diffuse degenerative cellular changes, and a fair degree of multilobular cirrhosis. The changes in the kidneys were almost entirely confined to the epithelium of the tubules, the nuclei of which were degenerate or absent, and to the cytoplasmic granules.

The liver-copper value was very low, only 5.7 p.p.m. on a dry-matter basis with a corresponding blood-copper value of $0.06 \mathrm{mg}$./100 ml.

This animal was in extremely poor condition at death and the carcass was condemned by the meat inspector. The head appeared to be too large in proportion to the rest of the body, a characteristic reported in copper-deficient animals in Holland by Melchers \& Gerritson (1944).

\section{Calves}

Fig. 3 shows that blood-copper values were normal for 9 months until May 1948, after which there was a steady decline with increase in age. One 7 -month-old calf 
which died as a result of severe lung-worm infestation had a liver-copper value of I36 p.p.m. in the dry matter with a corresponding blood value of $0.11 \mathrm{mg} . / 100 \mathrm{ml}$. Both these values are within the normal range. It is noteworthy, however, that the calves on this farm never thrive well, are stunted and are susceptible to heavy lungworm infestations. Frequent worm-egg counts on faecal samples showed that the gastro-intestinal worm burden was never significantly high.

Fig. 2 shows that haemoglobin values were variable, but not significantly low, and followed the same trend as those for the cows.

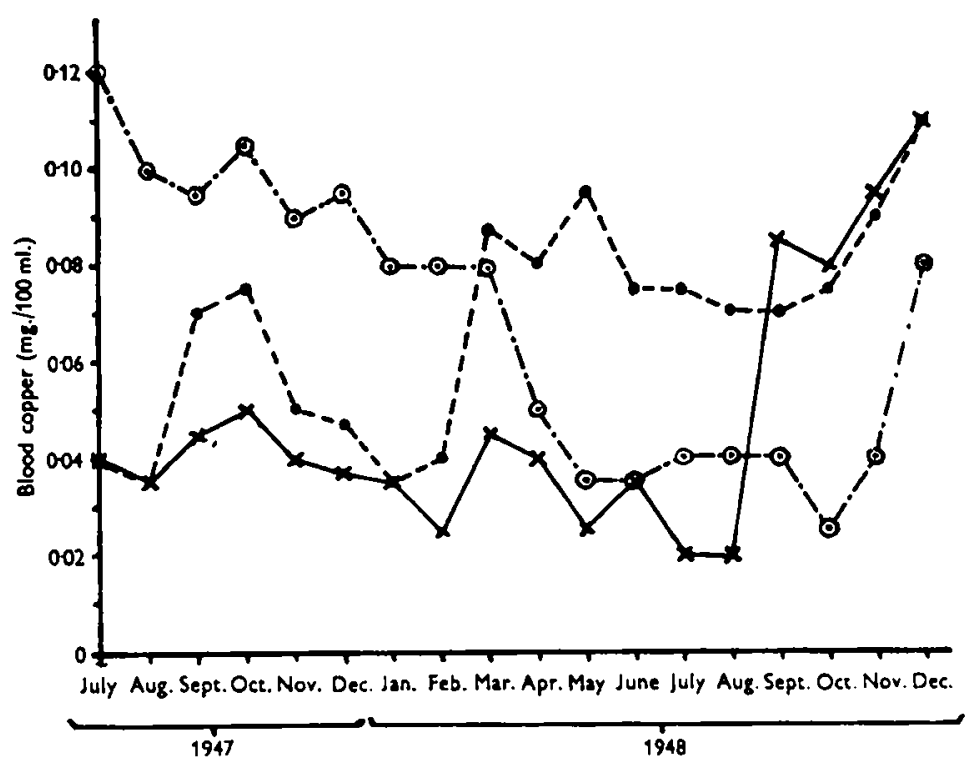

Fig. 4. Monthly blood-copper values for two heifers and one calf transferred from the experimental farm in Cheshire to the laboratory at Weybridge. $x-x$, heifer no. Ir $52 ; 0-\cdots$, , heifer no. 1153; $\odot-\cdots-\odot$, calf no. 1154 .

\section{Transferred animals}

These were in poor condition when they arrived at the laboratory and were very stunted for their age. Their coats were rough and staring and still held many of the long unshed winter hairs.

Fig. 4 shows blood-copper values for these three animals over a period of 17 months. With heifer no. 1152 values remained low for 13 months, never going above $0.05 \mathrm{mg}$./ roo ml., until September 1948 , when there was a sharp increase from 0.02 to $0.085 \mathrm{mg}$./ roo ml., continued by a further increase during November and December 1948. This increase was associated with calving early in August and transference to stalled conditions. Heifer no. II 53 showed a temporary increase in blood copper from 0.035 to $0.075 \mathrm{mg} . / 100 \mathrm{ml}$. during August-October 1947 followed by a fall to lower levels again until the end of February. Early in March this heifer was given $200 \mathrm{mg}$. copper intravenously to see if this amount would thereafter maintain normal blood levels. It can be seen that even after this treatment values fell slightly from $0.095 \mathrm{mg} . / 100 \mathrm{ml}$. 
in May to $0.07 \mathrm{mg} . / 100 \mathrm{ml}$. in August and September 1948. This heifer calved at the same time in August as no. 1152 and was likewise transferred from grazing to stalled conditions. This change did not result in such an immediate and marked increase as with no. II 52, but values rose steadily from October to December 1948 .

With the 6-month-old calf, no. I 54 , blood-copper values were normal $(0.12 \mathrm{mg}$. $100 \mathrm{ml}$.) on arrival at the laboratory and in this respect were similar to those of other calves of the same age on the experimental farm in Shropshire (see Fig. 3). Although values remained within normal limits $(0.12-0.08 \mathrm{mg} . / 100 \mathrm{ml}$.) for 8 months until March 1948 , there was during that period a steady decline followed thereafter by a sharp and unexpected fall to values as low as $0.025 \mathrm{mg} . / 100 \mathrm{ml}$. during the next 9 months. Towards the end of October 1948 this animal was brought inside and kept under stalled conditions similar to those of the other two, heifers nos. I I 52 and I I 53 . Again after this change from pasture to stall there was a sharp increase in blood copper from 0.04 to $0.08 \mathrm{mg} / 100 \mathrm{ml}$. from November to December 1948 .

In spite of these unexpectedly low blood-copper values after transference to normal pastures, the improvement in clinical condition of all three animals was evident after 6 months, and at the end of a year they had filled out and developed sleek coats and appeared normal in every way. The persistent diarrhoea which was present in the two heifers before they were sent to the laboratory cleared up immediately on arrival although they were kept at grass.

\section{Neighbouring farms}

Representative blood samples from nine dairy cows on farm L.E., where grazing is almost entirely on peat land but where crops are grown on adjacent higher loamy soil, showed low copper values ranging from 0.02 to $0.04 \mathrm{mg}$. $/ 100 \mathrm{ml}$. with a mean of $0.028 \mathrm{mg}$. $/ 100 \mathrm{ml}$. Haemoglobin values ranged from 9.0 to $1 \mathrm{r} \cdot 1 \mathrm{~g} . / 100 \mathrm{ml}$. with a mean of $10 . \mathrm{I} \mathrm{g} / 100 \mathrm{ml}$. It is interesting that, in spite of the very low copper values, these animals were in excellent condition and gave very satisfactory milk yields. It should be noted, however, that the level of nutrition on this farm was good, and ample crops were obtained from the higher loamy part of the farm.

Blood samples from twelve out of a herd of thirty-five cows on farm S., which contained only a small proportion of peat land, gave normal copper values of 0.08 $0.13 \mathrm{mg} . / 100 \mathrm{ml}$. with a mean of $0.10 \mathrm{mg} . / 100 \mathrm{ml}$.

On farm L.W., where scouring was very severe and milk production and general condition very poor, blood-copper values of six cows were all low, $0.01-0.03 \mathrm{mg}$. $/ 100 \mathrm{ml}$. Six weeks after daily drenching with $2 \mathrm{~g}$. A.R. copper sulphate per cow values increased from 0.05 to $0.10 \mathrm{mg} . / 100 \mathrm{ml}$. with a mean of $0.07 \mathrm{mg} . / 100 \mathrm{ml}$. During this period the diarrhoea was alleviated and the consistency of the dung became normal. The farmer reported a marked increase in milk yield in three of the cows. After this preliminary drenching trial all the cows were put on to $\mathrm{I} l \mathrm{lb}$./head/day of 'anti-teart' cake. During the next year there was a marked improvement in the clinical condition of the animals, no recurrence of the scouring and the farmer was satisfied with milk production. 


\section{DISCUSSION}

The results of these limited observations indicate that a low copper status of the adult animals on the experimental farm was a factor in the disease syndrome described, and that administration of copper produced a marked improvement in the condition. The fact that the group of animals receiving the complex mixture did not improve as rapidly as the group receiving copper only in larger amount suggests that a lack of other trace elements was not a contributory cause.

The syndrome differs from that described by Cunningham (1946) on peat land in New Zealand in two respects: (I) pasture-copper content was always normal, and indeed sometimes high, and (2) no anaemia was apparent in the animals.

It would appear, therefore, that, although the total copper content of the herbage was adequate, an insufficient amount was utilized by the animal. This might be due to some constituent in the herbage which either locked up the copper in the plant and rendered it unavailable to the cattle, or induced some dysfunction in the copper metabolism of the animal itself.

It is difficult to offer an explanation for the low blood-copper levels associated with good clinical condition in animals on farm L.E., but since they were not entirely dependent on food grown on the peaty portion of the farm it may merely be the result of reduced intake of the adverse factor present in herbage grown on peat land.

Cunningham (1946) also suggested that there may be some other factor or factors acting in conjunction with the deficiency of copper which cause the disease symptoms of 'peat scours' in New Zealand. He drew attention to the fact that the molybdenum content of 'peat scours' pastures ranged from 2.5 to II p.p.m., compared with values of $0.5-3.5$ p.p.m. in copper-deficient pastures where scouring did not occur, but other symptoms occurred which could be cured by copper supplements. He therefore put forward the hypothesis that 'peat scours' of cattle in New Zealand was the result of a small excess of molybdenum in the diet superimposed on a deficiency of copper.

Previous to this Dick \& Bull (1945) showed that ingestion of a total of 904 g. molybdenum as ammonium molybdate over a period of 3-4 years was associated with low liver-copper values in cattle, whereas a daily intake of 10 and $100 \mathrm{mg}$. molybdenum over a period of 6 months, with or without addition of extra copper, resulted in decreased storage of copper in the livers of sheep. They suggested that an increase in the molybdenum content of the pasture may explain the anomaly of the low copper status of ewes and the occurrence of swayback in lambs on pastures which show normal copper concentrations, as reported by Innes \& Shearer (1940) and Hunter, Eden \& Green (1945).

To get some information on this point molybdenum was determined on seven pasture samples from two farms in Derbyshire where the incidence of swayback was $25 \%$ and the copper status of the ewes was very low. Values of $0.6-1 \cdot 8$ p.p.m. in the dry matter were found. These are well within the normal range and, although the number of samples examined was small, the indication is that, at least in Derbyshire, an excess of molybdenum is not responsible for the low copper status of the sheep.

Further evidence in support of this view is the fact that, in spite of a high experi- 
mental administration of molybdenum (up to $280 \mathrm{mg}$. daily) to hypocupraemic sheep over a period of 14 months, blood-copper values rose from the low pre-treatment value of $0.03 \mathrm{mg} . / 100 \mathrm{ml}$. to the normal value of $0.11 \mathrm{mg}$. $/ 100 \mathrm{ml}$. (Allcroft, 1949). From these limited observations it does not appear that excess molybdenum invariably reduces copper storage. More detailed observations on copper-molybdenum relationships will be reported later (Allcroft, 1949), and further discussion on this point can therefore be postponed.

There was some indication that adequacy of the general nutritional level of the cattle was a factor in the disorder encountered on the peat land on the Cheshire-Shropshire border, since animals on farm L.E., where their nutritional level was good, were in satisfactory condition even though their blood-copper levels were below normal. To get further information on this point extra concentrates at the rate of $3 \mathrm{lb}$./head/day are being given to cows in group C, but it is too early yet to assess any effect of the improvement in rations.

The normal blood-copper values of the calves over the first 6-9 months of age indicated that they were born with sufficient liver-copper reserves to maintain normal blood levels over this period, and in this respect differed from the 'pining' calves in Caithness (Jamieson \& Allcroft, 1949). The decrease in blood-copper levels at and after yearling stage on the Shropshire farm is probably due to the longer periods of grazing on the peat pastures with increase in age.

It is difficult, however, to account for the steady and marked fall in blood-copper values in calf no. I154 which was transferred to the laboratory, especially as this decrease was accompanied by improvement in condition. Nor can the continued low blood-copper values in heifer no. 1152 be explained. The rise in values after transference from grazing to stalled conditions that occurred in all three animals is extremely interesting and suggests that the adverse factors which kept the values low during grazing no longer operated under stalled conditions. In this connexion it is interesting to note that, in spite of long-continued daily ingestion of $2 \mathrm{~g}$. copper sulphate over a period of 13 months, the blood-copper values in group A cows on the experimental farm never rose above an average of $0.09 \mathrm{mg} . / 100 \mathrm{ml}$., and individual values for this group never exceeded $0.10 \mathrm{mg} . / 100 \mathrm{ml}$. In contrast to this, Ferguson (1943) found that administration of $2 \mathrm{~g}$. copper sulphate daily for 18 weeks to three stalled cows on winter rations resulted in an increase in mean values from 0.101 to $0.235 \mathrm{mg}$.) roo ml. Sixteen weeks after cessation of copper-sulphate dosing and turning the animals out to pasture, the mean value for two of the three cows left in the group had fallen to $0.089 \mathrm{mg} . / 100 \mathrm{ml}$.

The significance of the difference in behaviour in stalls and at pasture at Weybridge and at Jeallot's Hill (Ferguson, 1943) is not yet clear.

\section{SUMMARY}

I. A disorder affecting dairy cattle on peat land on the Cheshire-Shropshire border is described. The condition was characterized by severe persistent diarrhoea, unthriftiness, low milk production and lowered fertility in cows and a marked degree of stunting in young stock. 
2. This condition was associated with low blood-copper levels in the adult animals, values of $0.02-0.04 \mathrm{mg} . / 100 \mathrm{ml}$. with a mean of $0.028 \mathrm{mg}$. $/ 100 \mathrm{ml}$. being obtained in twenty-one cows before any treatment was started. Haemoglobin values were variable, ranging from 7.6 to $12.6 \mathrm{~g} . / 100 \mathrm{ml}$. with a mean of $9.7 \mathrm{~g} . / 100 \mathrm{ml}$. Limited haematological studies indicated that there was no anaemia.

3. Pasture analyses showed normal copper contents. Samples from six fields taken at quarterly intervals throughout the year gave values of $8.7-22.7$ p.p.m. in the dry matter with a mean of 14.2 p.p.m. Molybdenum values for the same pastures ranged from 2.3 to 7.3 p.p.m. in the dry matter with a mean of 4.4 p.p.m.

4. Daily administration of $2 \mathrm{~g}$. copper sulphate incorporated in a high-protein cattle cake to each of a group of eight cows over a period of 14 months resulted in an increase of blood-copper values to normal levels, average monthly values of 0.07 $0.09 \mathrm{mg}$. $/ 100 \mathrm{ml}$. being obtained. A marked improvement in clinical condition occurred concomitantly with control of the previous persistent diarrhoea.

5. To another group of seven cows about one-third this amount of copper (about $160 \mathrm{mg}$. daily) was given in a mineralized cube, which also supplied extra cobalt and iodine as well as calcium, phosphorus, sodium, chlorine, sulphur, iron, manganese and nickel. This resulted in increased blood-copper values, but the monthly averages of $0.05-0.08 \mathrm{mg} . / 100 \mathrm{ml}$. which were obtained were always lower than those found in the group getting the larger amount of copper. There was an associated improvement in clinical condition, but this was never as marked as in the higher copper group. This indicates that a lack of trace elements other than copper was not a factor in this disorder.

6. In an untreated control group of five cows blood-copper levels remained low throughout the experimental period of 14 months, mean monthly values ranging from 0.028 to $0.045 \mathrm{mg} . / \mathrm{r} 00 \mathrm{ml}$.

7. Blood-copper values in a group of six untreated calves $\mathrm{I}-4$ months of age remained within the normal range for 9 months, after which there was a steady decline over the next 5 months, associated with grazing for longer periods on the peat pastures.

8. Transference of two 2-year-old heifers and one 6-month-old calf from the experimental farm in Shropshire to pasture at the Weybridge laboratory resulted in a marked improvement in clinical condition but not in increased blood-copper values. With the calf there was a decrease from the normal value of $0.12 \mathrm{mg} . / 100 \mathrm{ml}$. to the low value of $0.025 \mathrm{mg} . / 100 \mathrm{ml}$. during 15 months. Change from grazing to winter feeding in stalls resulted in an increase in blood-copper values in all three animals.

9. 'The effect of a high molybdenum intake on blood-copper values is briefly discussed.

Our thanks are due to $\mathrm{Dr} \mathrm{H}$. H. Green for advice and criticism; to $\mathrm{Mr} \mathrm{C}$. W. Clarke and other members of the Biochemical Department at Weybridge for assistance in analytical work; and to $\mathrm{Mr}$ Ivins and his family for the use of animals, and willing co-operation in the experimental work. 


\title{
REFERENCES
}

Allcroft, R. (1946). Nature, Lond., 158, 796.

Allcroft, R. (1949). (In preparation.)

Bennetts, H. W. \& Beck, A. B. (1942). Bull. Coun. Sci. industr. Res. Aust. no. 147.

Bennetts, H. W. \& Chapman, F. E. (1937). Aust. vet. F. 13, 138.

Bennetts, H. W. \& Hall, H. T. B. (1939). Aust. vet. F. 15, 152.

Brouwer, E., Frens, A. M., Reitsma, P. \& Kalisvaart, C. (1938). Versl. RijkslandbProefst. Hoorn, no. 44 (4) C., p. 267.

Cunningham, I. J. (1944), N.Z. F. Agric. 69, 559.

Cunningham, I. J. (1946). N.Z. F. Sci. Tech. 27, sect. A, p. 381 .

Dick, A. T. \& Bull, L. B. (1945). Aust. vet. F. 21, 70.

Eden, A. \& Green, H. H. (1940). Biochem. F. 34, 1202.

Ferguson, W. S. (1943). F. agric. Sci. 33, I 16.

Ferguson, W. S., Lewis, A. H. \& Watson, S. J. (1943). F. agric. Sci. 33, 44.

Hunter, A. H., Eden, A. \& Green, H. H. (1945). F. comp. Path. 55, 19.

Innes, J. R. M. \& Shearer, G. D. (1 940). F. comp. Path. 53, I.

Jamieson, S. \& Allcroft, R. (1949). (In preparation.)

Jamieson, S. \& Russell, F. C. (1946). Nature, Lond., I57, 22.

Melchers, W. J. \& Gerritsen, H. J. (1944). Koper als Onmisbaar Element voor Plant en Dier. Wageningen: Gebr. Zomer en Keuning.

Neal, W. M., Becker, R. B. \& Shealy, A. L. (1931). Science, 74, 418.

Newcomer, H. S. (1923). F. biol. Chem. 55, 569.

Perrin, D. D. (1946). N.Z. Y. Sci. Tech. 27, sect. A, p. 396.

Sjollems, B. (1933). Biochem. Z. 267, 151.

Sjollema, B. (r938). Biochem. Z. 295, 372.

\section{Haematuria in Pyridoxin-Deficient Rats}

\author{
By L. R. C. AGNEW \\ Rowett Research Institute, Bucksburn, Aberdeenshire
}

(Received 3 May 1949)

During studies on antibody production in pyridoxin-deficient hooded rats (Agnew \& Cook, 1948-9), gross macroscopic haematuria was noted in several animals fed a pyridoxin-deficient diet, but not in corresponding litter-mate inanition-control (paired-weighed) rats, or in rats fed the complete diet ad lib. It was impracticable at that time to investigate the matter fully, and only a preliminary note of the incidence and duration of these macroscopic haematurias was published (Agnew, I948-9). As haematuria has not been reported in any of the numerous recent papers from the United States on pyridoxin deficiency, and only Birch (1938) appears to have commented on this matter, it seemed of interest to make a detailed study of the incidence, duration and severity of the haematuria which was so regularly observed in our pyridoxindeficient rats. The effect of the haematuria on the peripheral blood picture (red cell count and haemoglobin content) was also studied, as well as the effect of giving pyridoxin to rats with well-established haematuria. Finally, possible strain differences in susceptibility to haematuria were sought by observing the effect of pyridoxin deficiency in Wistar albino rats fed the same diet as the hooded Lister rats. 